\title{
Salt Tolerance at Germination of Two Forage Grasses for Reclamation of Salinity Habitats
}

\author{
Alireza Shahriari ${ }^{1}$ \\ ${ }^{1}$ Faculty of Natural Resources, University of Zabol, Zabol, Iran \\ Correspondence: Alireza Shahriari, Faculty of Natural Resources, University of Zabol, PO box98615-538, Zabol, \\ Iran. Tel: 98-091-5541-7882. E-mail: nimaaryan2002@yahoo.com
}

Received: September 12, 2011

Accepted: June 1, 2012 Online Published: June 12, 2012

doi: $10.5539 /$ mas.v6n7p36

URL: http://dx.doi.org/10.5539/mas.v6n7p36

\begin{abstract}
Environmental stresses are among the most limiting factors to crop plant productivity. Salinity is one of the most detrimental ones. Establishment of seedlings at early growth stages of crop plants as one of the most important. Determinants of high yield are severely affected by soil salinity. Therefore, high germination rate and vigorous early growth under salty soils is preferred. Aeluropus lagopoides and A. littoralis are perennial grasses distributed in many saline areas and they are important economic plants used for sand fixation, pastures and other purposes. Seed germination is the critical stage for species survival. Seeds of halophytes usually show optimal germination in freshwater similar to glycophytes, but differ in their ability to germinate at higher salinities. The main objective of this study was to determine seed germination percentages and rates of Aeluropus lagopoides and A. littoralis when exposed to increased salinity. Mature seeds were collected from natural populations and a factorial complete randomized design of seven salinity levels 0 (control), 75, 150, 225, 300,375 and $450 \mathrm{mM} \mathrm{NaCl}$ were used. Seeds were incubated in light at $25^{\circ} \mathrm{C}$ and checked daily for 14 days. Maximum germination occurred in absence of salt, and salinity significantly decreased germination percentages and rates. The highest and the lowest resistance to increased salinity were observed in Aeluropus littoralis and Aeluropus lagopoides respectively. Thus, Aeluropus littoralis is more suitable than Aeluropus lagopoides for reclamation of salinity habitats.
\end{abstract}

Keywords: germination, salinity, grass, Aeluropus lagopoides, Aeluropus littoralis

\section{Introduction}

Biotic and abiotic stresses affect germination and the growth of plants (Saberi et al., 2011). Saline soils are a major environmental, agricultural and community problem in arid and semi-arid regions, where soil salt content is high and precipitation is insufficient to leach them. In these regions, planting salt-tolerant species, particularly N2-fixing species, is the most useful approach to rehabilitating salt-affected degraded lands (Oba et al., 2001). About $23 \%$ of the world's $1.5 \times 109$ ha of cultivated land is saline and $37 \%$ is sodic. Approximately one third of the world's irrigated land is salt-affected due chiefly to unsustainable irrigation practices (Khan \& Duke, 2001). Salinity induced inhibition of plant growth may occur due to the effects of high $\mathrm{Na}^{+}, \mathrm{Cl}^{-}$or $\mathrm{SO}_{4}{ }^{2-}$ by decreasing the uptake of essential elements such as $\mathrm{P}, \mathrm{K}, \mathrm{NO}_{3}$ and $\mathrm{Ca}$; ion toxicity or osmotic stress (Zhu, 2002).

Salts can affect seed germination either by restricting the supply of water (osmotic effect) or causing specific injury through ions to the metabolic machinery (ionic effect). Moreover most seeds are located near the soil surface, where salt concentration changes due to continuous evaporation of ground water (Ungar, 1991). However, rainfall can quickly leach salt from the surface and supply water to the seed. Thus, for successful establishment of plants in saline environments, seeds must remain viable in high salinity conditions and germinate when salinity decreases (Khan \& Ungar 1997). Halophyte seeds are known to remain viable for extended periods of time during exposure to high salinity and germinate when salinity is reduced (Khan \& Ungar, 1998; Berrichi et al., 2010). Salinity and its effects on biomass production have been considered by numerous authors (Mehari et al., 2005; Maghsoudi \& Maghsoudi, 2008). Salt tolerance of halophytic grasses varies with the ecotype, species, habitat and other environmental factors (Gulzar et al., 2003b). Plants of grasses like Urochondra setulosa can survive salinities of up to $1000 \mathrm{mM} \mathrm{NaCl}$ (Gulzar et al., 2003a), while seeds of a number of grasses survive in salinity (550 to $600 \mathrm{mM} \mathrm{NaCl}$ ) approaching seawater (Hester et al., 2001). Some 
grasses grow in soil salinities ranging between 300 to $500 \mathrm{mM} \mathrm{NaCl}$ (Bell \& O'Leary, 2003; Peng et al., 2004), while others cannot survive in a salt concentration above $300 \mathrm{mM} \mathrm{NaCl}$ (La Peyre \& Row, 2003).

Aeluropus lagopoides and A. littoralis (Linn.) Trin. Ex Thw. (Poaceae) are salt-secreting rhizomatous perennial grasses distributed from northern Africa (Morocco to Somalia), Sicily and Cyprus, through the Middle East to Central Asia, Iran, Pakistan and India (Cope, 1982). Aeluropus lagopoides and A. littoralis are distributed in many sandy and saline areas of deserts in Iran. Species of Aeluropus occur in saline habitats and could be used to reclaim salinized agricultural and rangeland. Since both of these grasses are extensively used as fodder in developing countries (Gulzar et al., 2003a), they have great potential for use as forage, silage and for biological reclamation of saline wastelands. They are also used for sand fixation, pastures and other purposes. These grasses are capable of vegetative reproduction through rhizome growth after monsoon rains and also can produce numerous flowers and seeds from April to October (Gulzar \& Khan, 2001). They are often found in association with Cressa cretica in the inland communities and with Cyperus arenarius, Cressa cretica, and Halopyrum mucronatum in coastal communities located at the backwaters of the Hamoon Wetland in Iran. Indeed, little information is available on the salt tolerance of these two species of Aeluropus in Iran. Therefore, the purpose of this investigation was to examine effects of seven concentrations of $\mathrm{NaCl}$ on seed germination percentage and speed of Aeluropus lagopoides and A. littoralis.

\section{Materials and Methods}

Mature seeds were collected from natural populations in the four natural populations (Iran).

These species include two species are A. littoralis and A. lagopoides for any two samples from different growing regions were considered, so that $A$. littoralis source of the Qom river and Mighan desert and A. lagopoides source of Hoveize and Darkhovin chosen.

Seeds were separated from inflorescence in the laboratory, then cleaned and dry-stored in a refrigerator at $4{ }^{\circ} \mathrm{C}$ after surface sterilization with $10 \%(\mathrm{v} / \mathrm{v})$ sodium hypochlorite. Seeds were germinated in $10 \mathrm{~cm}$ diameter Petri dishes on one sheet of Whatman No.1 filter paper, moistened with $5 \mathrm{ml}$ of the test solution. The Petri dishes were sealed with transparent tape. Fifty seeds were used for each treatment with four replicates each. We used a factorial complete randomized design swith even salinity treatments of 0 (control), 75, 150, 225, 300, 375 and $450 \mathrm{mM} \mathrm{NaCl}$. The experiment was conducted in a programmed incubator at $25^{\circ} \mathrm{C}$ with a $14: 10 \mathrm{hr}$ light/dark cycle each day and at $70 \%$ relative humidity.

Germination was recorded on alternate days (every $48 \mathrm{~h}$ ) for 14 days. Germination percentage and rate were measured, Rate of germination was calculated with a modified Timson's germination velocity index: $£ \mathrm{G} / \mathrm{T}$, where $\mathrm{G}$ is the percentage of seed germinated after $2 \mathrm{~d}$ intervals, and $\mathrm{T}$ is the total time of germination (Khan $\&$ Ungar, 1998).

Statistical analyses were carried out using SPSS version 10. A one-way ANOVA was used to determine the differences among treatment group means for percent germination, rate of germination and recovery percent germination A Duncan's multiple comparison test was also done to determine if significant $(\mathrm{p}<0.05)$ differences occurred between individual treatments.

It should be noted that the habitat A. lagopoides Hoveize of germination was very low (even in control conditions (1/5 percent)). Therefore was excluded from analysis of data and data analysis was done with other species. For ease of analysis and conclusions presented in each habitat was given a code. A. lagopoides of habitat for Darkhovin Code 1, Code 2 for $A$. littoralis of Qom river habitat for the desert $A$. littoralis Mighan code 3 was considered.

\section{Results}

Results of variance analysis the effects of concentrations of $\mathrm{NaCl}$ on $A$. lagopoides and A. littoralis on properties included germination percentage and germination speed were reported in Table 1. 
Table 1. A one-way ANOVA of the effects of salinity species and their interaction on germination of species seeds

\begin{tabular}{cccccc}
\hline Source of variation & Sum of Squares & df & Mean Square & F & P \\
\hline Effect of salinity & 23311.717 & 6 & 3885.286 & 6.526 & $0.00^{* *}$ \\
Effect of Species & 30728.496 & 2 & 15364.382 & 32.388 & $0.00^{* *}$ \\
Effect of interaction & 66440.634 & 20 & 3322.032 & 77.141 & $0.00^{* *}$ \\
salinity and species & & & & & \\
\hline
\end{tabular}

** Significant at 0.01 level of probability

A one-way ANOVA indicated significant individual effects $(\mathrm{P}<0.01)$ of salinity, species and their interaction on percent and rate of germination of Aeluropus seeds. Mean comparison Duncan's multiple indicated significant difference $(\mathrm{P}<0.01)$ between species seed germination (Table 2).

Table 2. The effect of species on seed germination

\begin{tabular}{ccc}
\hline Code & Mean germination & Class \\
\hline 1 & 4.02 & $\mathrm{c}$ \\
2 & 43.88 & $\mathrm{a}$ \\
3 & 13.33 & $\mathrm{~b}$
\end{tabular}

$\mathrm{a}, \mathrm{b}, \mathrm{c}$ : denote significant difference among species at 0.01 level of probability

Results showed that germination percentage of A. lagopoides and A. littoralis was reduced when $\mathrm{NaCl}$ concentrations increased. Maximum germination for code $1(16.43 \%)$, code $2(90.43 \%)$ and code $3(44 \%)$ was related to control treatment (Figure 1). though maximum seed germination percentage was related to control treatment (Figure 1).

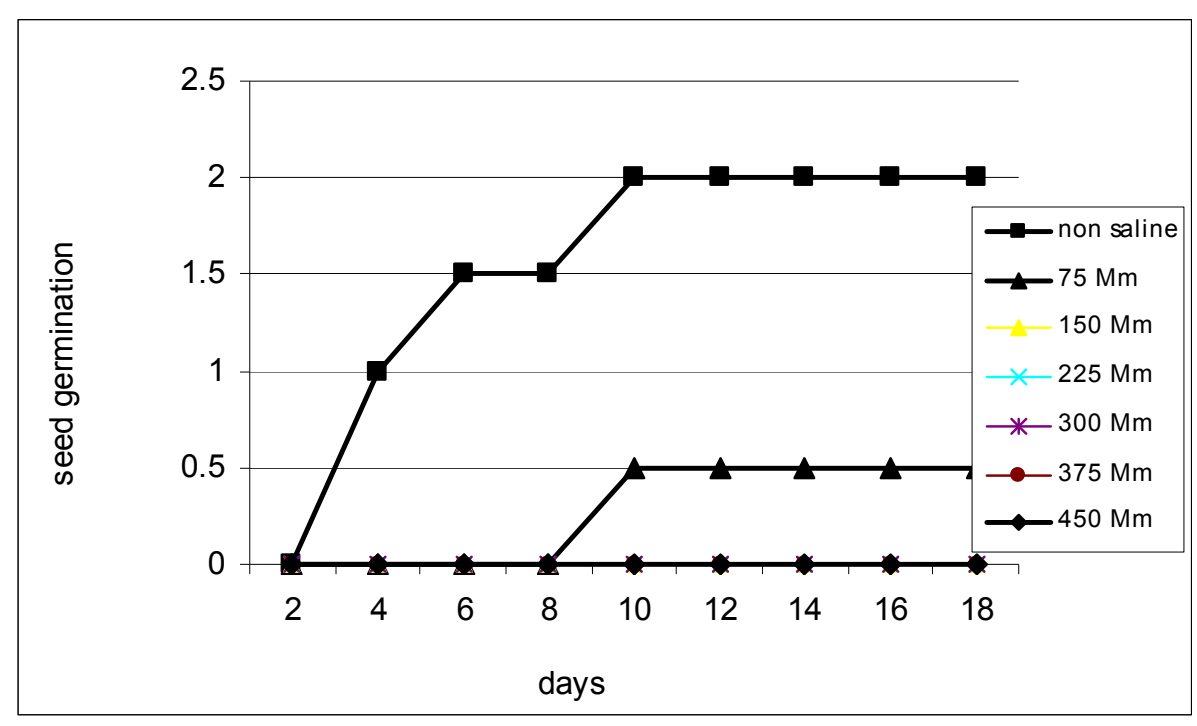

Figure 1. Germination percentage of species seeds in different salinity

Cumulative mean percent germination of species seeds over time in $0,75,150,225,300,375$ and $450 \mathrm{mM} \mathrm{NaCl}$ in $14 \mathrm{~h}$ light: $10 \mathrm{~h}$ dark photoperiod and $70 \%$ relative humidity (Figures 2, 3, 4). 


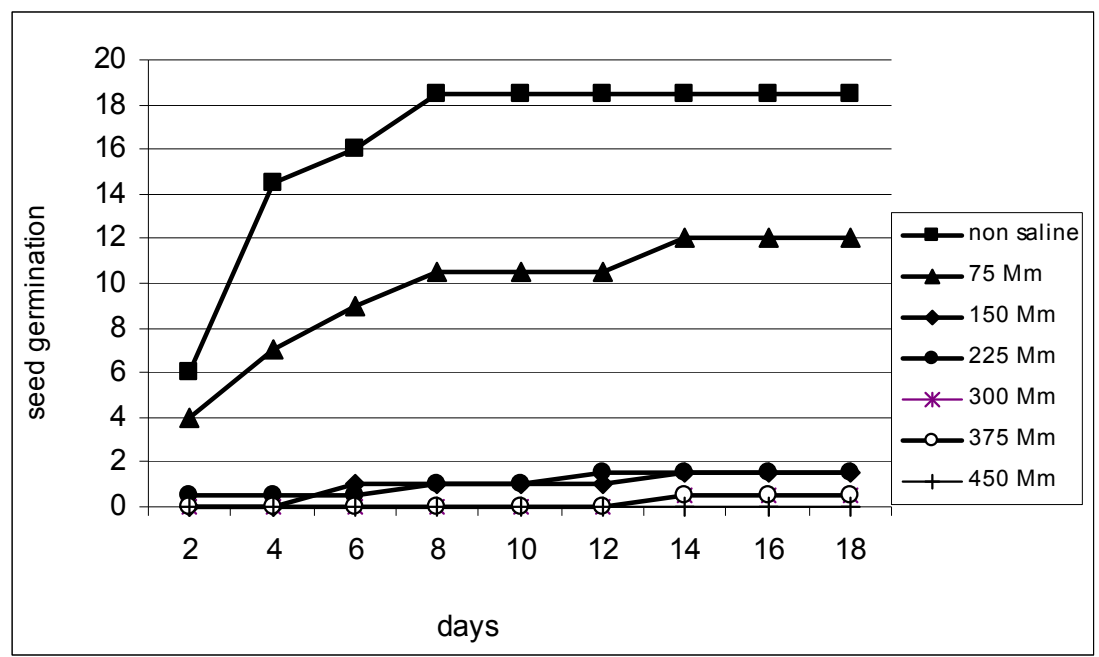

(a)

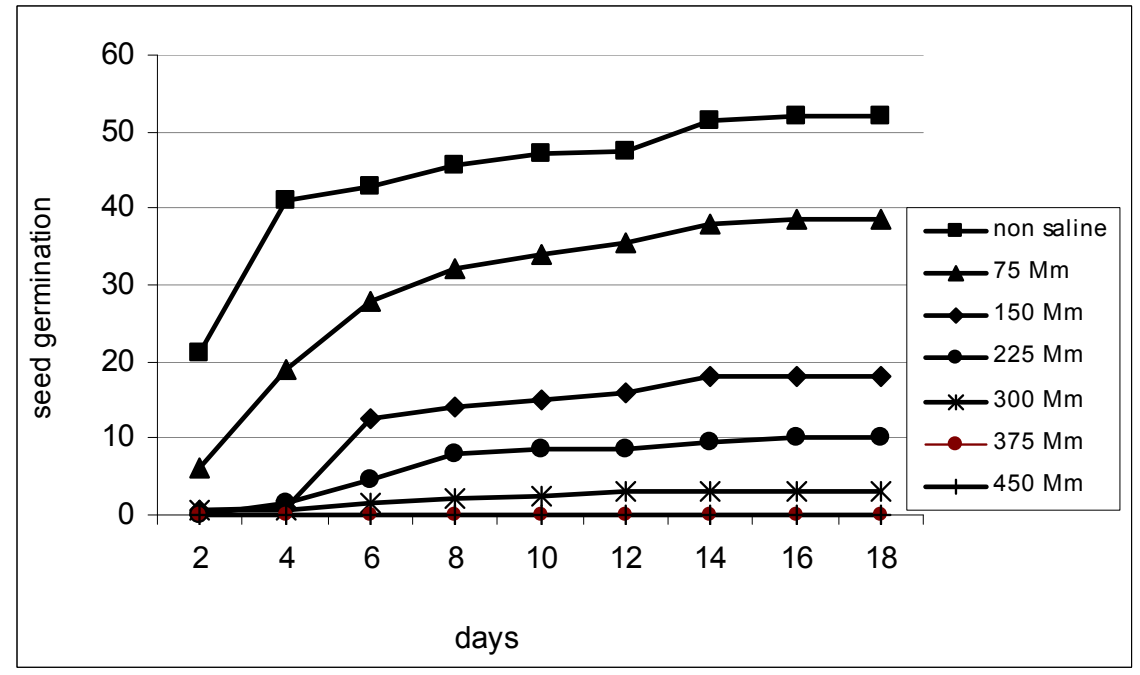

(b)

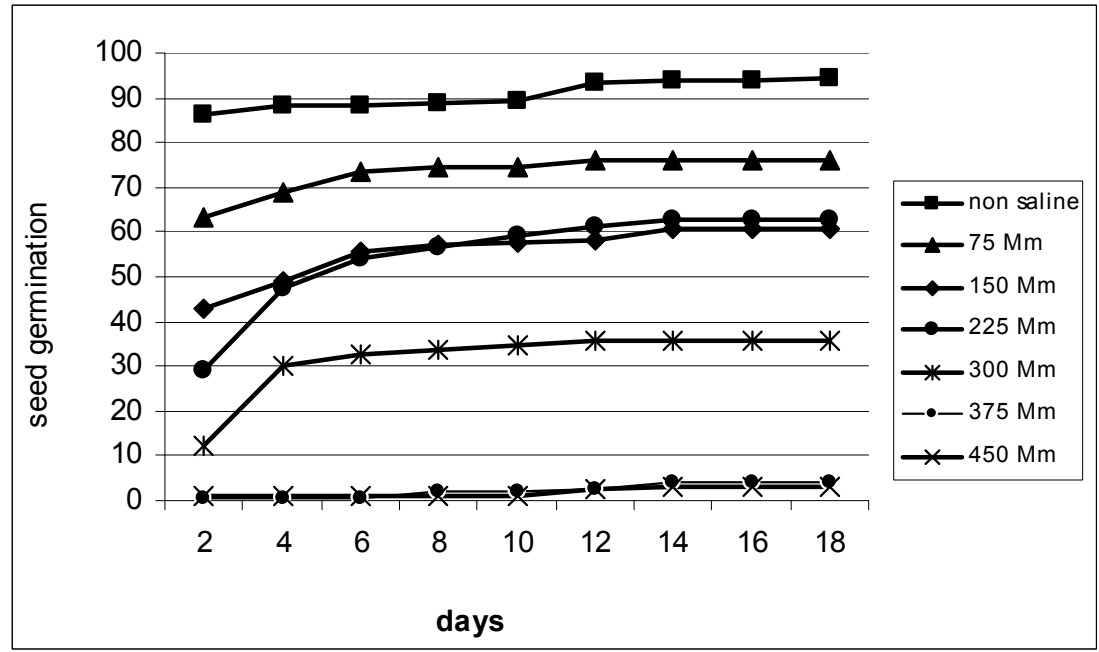

(c)

Figure 2. Mean final percent germination of Aeloropus sp. in various salinity: (a) Code 1 (b) Code 2 (c) Code 3 


\section{Discussion}

Ion ratios could be helpful in categorizing the physiological response of a plant (salt excluding, salt-secreting or salt-diluting) in relation to ion selectivity under increasing substrate salt concentrations (Wang et al., 2002).

Although most halophyte species control accumulation of inorganic ions as the basic mechanism to adjust the osmotic potential so their internal tissues to protect against external salinity, they differ widely in the extent to which they accumulate inorganic ions (Ghassemi-Golzani et al., 2011). Even between species of a single genus, this difference is sometimes of such a high level that efficient salt-tolerant species can be screened within a single genus (Khan et al., 2002). Aeluropus species are said to respond differently to salinity.

The test species differed greatly in their response to salinity, as quantified by the percentage germination and the results showed a significant effect of salinity on germination percentage $(\mathrm{P}<0.01)$. Despite high tolerance of halophytes to salt, maximum germination occurred in the salt free condition, as maximum germination for code $1(16.43 \%)$, code $2(90.43 \%)$ and code $3(44 \%)$ was obtained in non-saline control and it decreased in $450 \mathrm{mM}$ $\mathrm{NaCl}$. Therefore increase in salinity progressively inhibited germination. Gulzar and Khan (2001) reported best germination of halophytic grasses is obtained under nonsaline conditions and their germination decreases with increases in salinity.

Grasses seeds usually are not very tolerant of increased salinity (Khan \& Ungar, 2001), and the maximum salt tolerance for germination usually ranges between 250 and $350 \mathrm{mmol} / \mathrm{L} \mathrm{NaCl}$ (Morgan and Myers, 1989; Gulzar \& Khan, 2001). Spartina alterniflora is an exception; it can germinate at concentrations higher than $400 \mathrm{mmol} / \mathrm{L}$ $\mathrm{NaCl}$ (Mooring et al., 1971). It appears from our data that halophytic grasses from coastal areas of Iran are among the highly salt tolerant grasses at germination stage and have the ability to germinate in warm conditions.

The highest and the lowest salt resistance were observed in Aeluropus littoralis and Aeluropus lagopoides respectively. Recruitment of Aeluropus spp. in natural conditions through seed germination appears to take place after monsoon rains. Germination of halophyte seeds in subtropical coastal and inland salt marshes usually occurs after monsoon rains, which causes a reduction in temperature and a lowering of soil salinity (Khan \& Gul 1998; Khan \& Ungar 1998). Therefore salinity has posed adverse effects on germination of the species. These results are consistent with other studies (Ashraf \& McNeilly, 1986; Ashraf et al., 1989) where germination inhibition under saline condition has been reported for grass species.

Since seeds of A. lagopoides are highly sensitive to salinity, the species is unable to propagate through seeds in nature unless salinity is greatly reduced. Thus, Aeluropus littoralis is more suitable than Aeluropus lagopoides for reclamation of salinity habitats.

In summary, our results showed that $A$. littoralis is a highly salt tolerant halophytic grass, and it may be used as a turf grass in the areas where freshwater is not available or to stabilize sand dunes both in the coastal and inland saline deserts of Iran. Gulzar et al. (2003a) indicated that Aeluropus species could also be used in increasing forage production in salt affected wastelands because of its high protein content and high salinity tolerance. This grass is used locally as a fodder for livestock and could be useful in coastal sand dune stabilization. It is currently being grown experimentally in the field as a fodder using brackish water irrigation.

\section{Conclusion}

The in vitro study of the germination of seed Aeluropus plant under saline stress enabled us to conclude that concentrations of $\mathrm{NaCl}$ limited the seeds germination. The salt seemed to affect the opening of the plumule rather than germination. These results can important to understanding of salinity mechanisms and founding solutions to prevent of infiltration of these elements to valuable grassland plants. A total this grass is used locally as a fodder for livestock and could be useful in coastal sand dune stabilization. It is currently being grown experimentally in the field as a fodder using brackish water irrigation.

\section{Acknowledgements}

This research was supported by the Natural Resources Gene Bank Research Institute of Forests and Rangelands.

\section{References}

Ashraf, M., \& McNeilly, T. (1986). The responses of selected tolerant lines of four grass species to $\mathrm{NaCl}$ in sand culture. New Phytologist, 104, 453-561. http://dx.doi.org/10.1111/j.1469-8137.1986.tb02912.x

Ashraf, M., McNeilly, T., \& Bradshaw, A. D. (1989). The potential for evolution of tolerance to sodium chloride, calcium chloride, magnesium chloride and sea water in four grass species. New Phytologist, 112, 245-254. http://dx.doi.org/10.1111/j.1469-8137.1989.tb02380.x 
Bell, H. L., \& O'Leary, J. W. (2003). Effects of salinity on growth and cation accumulation of Sporobolus virginicus (Poaceae). Am. J. Bot., 90, 1416-1424. http://dx.doi.org/10.3732/ajb.90.10.1416

Berrichi, A., Tazi, R., Bellirou, A., Kouddane, N., \& Bouali, A. (2010). Role of salt stress on seed germination and growth of Jojoba plant Simmondsia chinensis (link) schneider. IUFS J Biol, 69(1), 33-39.

Cope, T. A., Nasir, E., \& Ali, S. I. (1982). Poaceae In Flora of Pakistan (Chapter 2) (Eds). University of Karachi, Karachi, Pakistan.

Ghassemi-Golzani, K., Zehtab-Salmasi, S., \& Dasborhan, S. (2011). Changes in essential oil content of dill (Anethum graveolens) organs under salinity stress. Journal of Medicinal plant Research, 5(14), 3142-3145. Retrieved from http//www.academic journals.org/JMPR

Gulzar, S., \& Khan, M. A. (2001). Seed germination of a halophytic grass. Aeluropus lagopoides. Ann. Bot., 87, 319-324. http://dx.doi.org/10.1006/anbo.2000.1336

Gulzar, S., Khan, M. A., \& Ungar, I. A. (2003a). Effects of Salinity on growth, ionic content and plantwater relations of Aeluropus lagopoides. Comm. Soil Sci. Plant Anal., 34, 1657-1668. http://dx.doi.org/10.1081/CSS-120021303

Gulzar, S., Khan, M. A., \& Ungar, I. A. (2003b). Salt tolerance of a coastal salt marsh grass. Comm. Soil Sci. Plant Anal., 34, 2595-2605. http://dx.doi.org/10.1081/CSS-120024787

Joshi, A. J., Mali, B. S., \& Hinglajia, H. (2004). Salt tolerance at germination and early growth of two forage grasses growing in marshy habitats. Environmental and Experimental Botany, 54(3), 267-274. http://dx.doi.org/10.1016/j.envexpbot.2004.09.005

Khan, M. A., \& Duke, N. C. (2001). Halophytes-A resource for the future. Wetlands Ecology and Management 6, 455-456. Netherlands: Kluwer Academic Publishers. http://dx.doi.org/10.1023/A:1012211726748

Khan, M. A., \& Gul, B. (1998). High salt tolerance in germinating dimorphic seeds of Arthocnemum indicum. Int. J. Plant Sei., 159, 826-832. http://dx.doi.org/10.1086/297603

Khan, M. A., Gul, B., \& Weber, D. J. (2002). Seed germination in the great basin halophyte Salsola iberica. Canadian Journal of Botany, 80(2002), 650-655. http://dx.doi.org/10.1139/b02-046

Khan, M. A., \& Ungar, I. A. (1997). Effect of thermo period on recovery of seed germination of halophytes from salin conditions. Am. J. Bot., 84, 279-283. http://dx.doi.org/10.2307/2446089

Khan, M. A., \& Ungar, I. A. (1998). Germination of salt tolerant shrub suaeda fruticosa from Pakistan: Salinity and temperature responses. Seed Science and Technology, 26, 657-667.

Khan, M. A., \& Ungar, I. A. (2001). Alleviation of salinity stress and the response to temperature in two seed morphs of Halopyrum mucronatum (Poaceae). Aust. J. Bot., 49, 777-783. http://dx.doi.org/10.1071/BT01014

Le Peyre, M. K., \& Row, S. (2003). Effects of salinity changes on growth of Ruppia maritima L.Aquat. Bot., 77, 235-241. http://dx.doi.org/10.1016/S0304-3770(03)00109-8

Maghsoudi Moud, A., \& Maghsoudi, K. (2008). Salt Stress Effects on Respiration and Growth of Germinated Seeds of Different Wheat (Triticum aestivum L.) Cultivars. World Journal of Agricultural Sciences, 4(3), 351-358.

Mehari, A., Ericsson, T., \& Weih, M. (2005). Effects of $\mathrm{NaCl}$ on seedling growth, biomass production and water status of Acacia nilotica and A. tortilis. Journal of Arid Environments, 62(2005), 343-349. http://dx.doi.org/10.1016/j.jaridenv.2004.11.014

Mooring, M. T., Cooper, A. W., \& Seneca, E. D. (1971). Seed germination response and evidence for height of ecophenes in Spartina alterniflora from North Carolina. American Journal of Botany, 58, 48-56. http://dx.doi.org/10.2307/2441305

Morgan, W. C., \& Myers, B. A. (1989). Germination of the salt-tolerant grass Diplachne fusca. II. Salinity responses. Australian Journal of Botany, 37, 239-251. http://dx.doi.org/10.1071/BT9890239

Oba, G., Nordal, I., Stenseth, N. C., Stave, J., Bjora, C. S., Muthondeki, J. K., \& Bii, W. K. A. (2001). Growth performance of exotic and indigenous tree species in saline soils Turkana, Kenya. Journal of Arid Environment, 47, 499-511. http://dx.doi.org/10.1006/jare.2000.0734 
Peng, Y. H., Zhu, Y. F., Mao, Y. Q., Wang, S. M., Su, W. A., \& Tang, Z. C. (2004). Alkali grass resists salt stress through high $\left[\mathrm{K}^{+}\right]$and an endodermis barrier to $\mathrm{Na}^{+}$. J. Exp. Bot., 55, 939-949. http://dx.doi.org/10.1093/jxb/erh071

Saberi, M., Shahriari, J. A., Teixeira Tarnian, F., \& Tavili, A. (2011). Influence of Salicylic Acid on Bromus tomentellus Germination and Initial Growth Properties under Cadmium Stress. Plant Stress, 5(1). Global Science Books.

Ungar, I. A. (1991). Ecophysiology of vascular halophytes. CRC. Press, Boca Raton, U.S.A. (Chapter 3).

Wang, S., Zheng, W., Ren, J., \& Zhang, C. (2002). Selectivity of various types of salt-resistant plants for K ${ }^{+}$over $\mathrm{Na}^{+}$. J. Arid Environ., 52, 457-472. http://dx.doi.org/10.1006/jare.2002.1015

Zhu, J. K. (2002). Salt and drought stress signal transduction in plants. Ann. Rev. Plant Biol., 53, $247-273$. http://dx.doi.org/10.1146/annurev.arplant.53.091401.143329 